\title{
PENDIDIKAN KARAKTER BERBASIS AL-QUR'AN DAN AS-SUNNAH
}

\begin{tabular}{|c|c|}
\hline \multicolumn{2}{|c|}{$\begin{array}{c}\text { Muhamad Akip } \\
\text { STAI Bumi Silampari Lubuklinggau } \\
\text { muhammdaakip@gmail.com }\end{array}$} \\
\hline \multicolumn{2}{|r|}{ Abstrak } \\
\hline $\begin{array}{l}\text { Article History } \\
\text { Received : 28-01-2019 } \\
\text { Revised : 03-01-2019 } \\
\text { Accepted : 05-02-2019 }\end{array}$ & $\begin{array}{l}\text { This nation is looking for and } \\
\text { choosing an idea that can complete } \\
\text { the basalak education, which is } \\
\text { expected to be a solution and able to }\end{array}$ \\
\hline $\begin{array}{l}\text { Keywords: } \\
\text { Education, } \\
\text { Character, } \\
\text { Al-Qur'an } \\
\text { and Sunnah }\end{array}$ & $\begin{array}{l}\text { bring this nation to progress. In the } \\
\text { midst of the ambiguity of society in } \\
\text { the world of education, the new hope } \\
\text { is with the coming of the era of } \\
\text { character education sourced from the }\end{array}$ \\
\hline & $\begin{array}{l}\text { quran and hadith, through a } \\
\text { character-based holistic concept and } \\
\text { promoting nine pillars; love God and } \\
\text { all his creation, independence and } \\
\text { responsibility, honesty and }\end{array}$ \\
\hline & $\begin{array}{l}\text { trustworthy, diplomatic, respectful } \\
\text { and polite, generous and helpful, } \\
\text { confident and hardworking, } \\
\text { leadership and justice, humble, } \\
\text { tolerant, peaceful and united. }\end{array}$ \\
\hline
\end{tabular}

\section{Pendahuluan}

Pendidikan di dunia Islam saat ini mengalami krisis yang menyebabkan kemunduran, para pakar pendidikan telah menganalisis beberapa sebab terjadinya kemunduran itu, di antaranya adalah karena ketidaklengkapan aspek materi, terjadinya krisis sosial masyarakat dan krisis budaya, serta hilangnya qudwah hasanah (teladan yang baik) dan nilai-nilai agama ada juga yang melihat penyebab tersebut dikarenakan salah membaca eksistensi manusia, sehingga salah pula melihat eksistensi anak didik (Republika, Februari. 2010) 
Krisis pendidikan yang terjadi di dunia Islam ini juga dialami oleh seluruh dunia khususnya Indonesia dengan masalah yang dihadapi sangat beragam, mulai dari aspek sosial, polotik, budaya, ekonomi sampai ke krisis moral, meskipun akhir-akhir ini prestasi intlektual anak-anak banyak mengalami peningkatan yang cukup baik dengan beragam prestasi namun kemunduran terjadi pada aspek lain yaitu moralisasi, kemunduran pada aspek inilah yang menyebabkan krisis pendidikan akhlak dalam dunia pendidikan kita sehingga merambat ke berbagai aspek yang memacu kemerosotan yang terus terjadi. Pendidikan nasional yang disusun pemerintah melalui undang-undang sebenarnya sudah menekankan pentingnya pembangunan karakteristik anak didik hal ini terimplikasikan melalui pendidikan akhlak dalam hal pembinaan moral dan budi pekerti yang tercantum dalam UU sisdiknas tahun 2003.

Peranan peserta didik dalam kehidupan masyarakat, baik sebagai individu maupun sebagai anggota masyarakat merupakan keluaran (out put) dari sistem pendidikan yang berfungsi untuk mengembangkan kemampuan, meningkatkan mutu kehidupan dan martabat manusia, baik individu maupun sosial. Dengan kata lain pendidikan berfungsi sebagai sarana pemberdayaan individu dan masyarakat guna menghadapi masa depan. Pendidikan memiliki tujuan untuk membangun tatanan baru yang lebih baik dan menciptakan pribadi yang mandiri dan bermartabat. Demikian pendidikan Islam pun memiliki tujuan yang sama sebagaimana tujuan pendidikan umum, akan tetapi pendidikan Islam memiliki muatan nilai yang lebih bersifat transendental. Maka dengan demikian pendidikan dengan sendirinya menempati posisi yang sangat sentral dan strategis dalam membangun kehidupan sosial yang memposisikan manusia dalam pluralisme kehidupan yang berharkat dan bermartabat baik di sisi sesama makhluk maupun kholik. Secara umum mereka yang lulus sekolah dengan ahlak yang buruk ini akan menempati posisi-posisi di dunia kerja yang serat dengan persaingan, rendahnya moral dan rendahnya pelaku kebijakan juga akan diikuti oleh rendahnya etos kerja masyarakat, sehingga memungkinkan mereka akan terjebak dalam praktek-praktek korupsi yang sistematik. Melihat tujuan dan hakikat pendidikan itu sendiri, pendidikan karakter memiliki keterkaitan yang erat dengan masyarakat serta bagaimana pendidikan karakter mampu membebaskan masyarakat dari ketidakadilan dan pembodohan masal yang terjadi. Dalam tulisan 
ini akan membahas bagaimana pendidikan karakter berbasis alQur'an dan as-Sunnah yang mencakup aspek penamaan, tujuan pendidikan Islam, implementasi pendidikan karakter terhadap eksistensi manusia.

\section{Metode Penelitian}

Metode yang digunakan dalam tulisan menggunakan pendekatan penelitian kualitatif yang bermaksud untuk memahami kejadian atau peristiwa tentang apa akan dipecahkan berdasarkan pengumpulan data dan latar alamiah. Penelitian ini bersifat deskriftif yaitu menganalisis secara mendalam, fokus dan jelas. Kemudian jenis penelitian adalah studi literatur atau penelitian kepustakaan (library Research) memerlukan olahan dari fiosofis da teoritis dalam penelitian ini termasuk kategori bidang kewahyuan karena membicarakan tentang masalah Al-Quran dan Hadist. Adapun yang menjadi bahan kajian utama adalah Al-Qur'an , Hadist, Buku-buku yang relevan terhadap bahasan pendidikan karakter dan jurnal-jurnal.

\section{Pembahasan}

\section{Pengertian Pendidikan Karakter}

Beberapa pakar pendidikan di Indonesia telah berusaha memecahkan masalah pendidikan, mereka mencoba membuat konsep-konsep atau model pendidikan yang dapat mengurangi kelemahan pelaksanaan pendidikan, namun para konseptor masih banyak terjebak dalam epistemologi pendidikan barat sehingga konsep dan model yang dihasilkan tetap tidak dapat di lepaskan dari paradigma keilmuan barat yang mengambil logika sebagai sumber ilmu pengetahuan (Mujamil Qomar 2008: 218).

Kata karakter menurut kamus bahasa indonesia (2008) berarti sifat-sifat kejiwaan, akhlak atau budi pekerti yang membedakan seseorang dari yang lain, sedangkan karakter menurut pusat bahasa depdiknas memiliki arti bawaan hati, jiwa, keperibadian, budi pekerti, perilaku, personalitas, sifat tabiat atau watak, berkarakter sendiri di maknai dengan berkeperibadian, berperilaku, bertabiat dan berwatak jadi dapat dikatakan bahwa individu yang berkarakter baik adalah seseorang yang berusaha melakukan hal-hal yang terbaik terhadap makhluk dan khalik. 
Herman H. Horn (1962: 140) berpendapat, pendidikan harus dipandang sebagai suatu proses penyesuaian diri manusia secara timbal balik dengan alam sekitar, dengan sesama manusia dan dengan tabiat tertinggi dari kosmos. Sedangkan William Mc Gucken, seorang tokoh pendidikan katolik berpendapat, bahwa pendidikan diartikan oleh ahli scholastik, sebagai suatu perkembangan dan kelengkapan dari kemampuan-kemampuan manusia baik moral, intelektual, maupun jasmaniah yang diorganisasikan dengan atau untuk kepentingan individual atau sosial dan diarahkan kepada kegiatankegiatan yang bersatu dengan penciptaan sebagai tujuan akhirnya (Arifin, 1994: 13). Pendidikan dengan demikian memiliki fungsi bimbingan dan pengarahan ke arah tujuan akhir yang lebih baik. John Dewey mengartikan pendidikan sebagai proses bimbingan tanpa akhir dan merupakan instrumen, wahana untuk pendemokrasian. Adapun menurut Paulo Freire (1984: 41) bahwa pendidikan memiliki fungsi sebagai media dan instrumen pembebasan.

Konsep pendidikan Islam sendiri secara umum, mengacu pada makna dan asal kata pendidikan itu sendiri dalam hubungannya dengan ajaran Islam. terdapat tiga istilah yang biasa digunakan dalam pendidikan Islam. yaitu al-tarbiyah, al-ta'lim, dan al-ta'dib. Tarbiyah memiliki makna memelihara, membesarkan dan mendidik, dan dalam tarbiyah terkandung makna 'alama (Ahmad Tafsir, 1995: 109). Dari pengertian tersebut, maka tarbiyah didefinisikan sebagai proses bimbingan terhadap potensi manusia secara maksimal agar menjadi bekal dalam menghadapi kehidupan. Namun Naquib al-Attas merujuk makna pendidikan dari konsep ta'dib, karena pendidikan Islam lebih berorientasi pada ta'dib. Ta'dib baginya hanya mencakup pengertian pendidikan untuk manusia, berbeda dengan tarbiyah yang memiliki pengertian, serta cakupan yang lebih luas (Syed Naquib alAttas, 1979: 21).

Ketiga istilah ta'dib, tarbiyah, dan ta'lim semuanya merujuk kepada Allah, tarbiyah ditengarai merupakan benturan kata dari Rabbun atau rabba dalam hal ini mengacu kepada Allah sebagai Rabbun a'lamin, sedangkan ta'lim kosakata awal adalah 'allama, juga merujuk kepada Allah sebagai dzat yang maha 'Alim. Selanjutnya ta'dib sebagai makna termuat pada pernyataan Rasulullah SAW “addabani rabby fa ahsana ta'diby", dalam hal ini memperjelas bahwa sumber utama pendidikan adalah Allah SWT. 


\section{Karakteristik pendidikan Islam}

Pendidikan Islam merupakan upaya menusia untuk melahirkan generasi yang baik, yang selalu mengabdi kepada sang pencipta, dalam al-Qur'an Allah meminta kita agar tidak mewarisi generasi yang lemah dan tidak berkarakter.Allah berfirman:

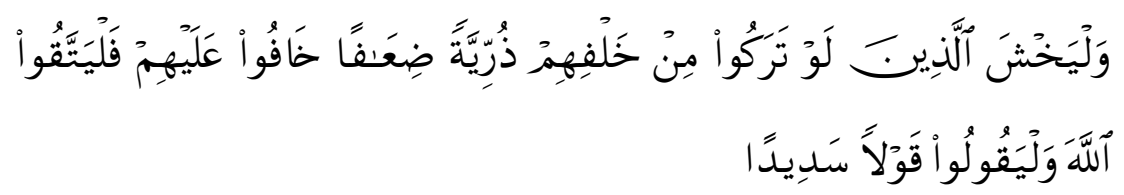

Artinya: Dan hendaklah takut kepada Allah orang-orang yang seandainya meninggalkan dibelakang mereka anak-anak yang lemah, yang mereka khawatir terhadap (kesejahteraan) mereka. oleh sebab itu hendaklah mereka bertakwa kepada Allah dan hendaklah mereka mengucapkan perkataan yang benar (Q.S. An-Nisaa:9).

Menurut Abdurrahman an-Nahlawy (1999:19), proses pendidikan Islam berupa mendidik manusia ke arah sempurna sehingga manusia tersebut dapat memikul tugas kekhalifahan di bumi ini yang harus memiliki tiga aspek, pertama pendidikan pribadi yang meliputi pendidikan tauhid kepada Allah dan nilai aqidah, kedua mencintai amal kebajikan, dan keteguhan hati dalam situasi dan kondisi apapun, Ketiga pendidikan sosial yang mencintai kebenaran dan mengamalkannya sehingga akan lahir manusia yang berakal, cerdas, amanah, berilmu dan takwa.

\section{Al-Qur'an dan proses pendidikan}

Al-Qur'an telah melakukan proses penting dalam pendidikan manusia sejak diturunkan wahyu pertama kepada Nabi Muhammad SAW, wahyu pertama tersebut mengajak seluruh manusia untuk memperoleh pengetahuan melalui proses membaca, ada dua alasan pokok yang bisa disebut bahwa al-Qur'an berperan besar dalam proses pendidikan manusia yang berkarakter, pertama al-Qur'an banyak menggunakan term-term yang mewakili dunia pendidikan seperti ilmu yang diungkapkan sebanyak 94 kali, hikmah 20 kali, dan yang menggambarkan proses berfikir 24 kali, belajar 68 kali, mendengar 19 kali dan bertanya sebanyak 25 kali. Kedua al-Qur'an mendorong manusia untuk berfikir dan melakukan analisa pada 
fenomena yang terjadi dalam kehidupan era sekarang (Abdurrahman An-Nahlawi, 1995: 42). Al-Qur'an memiliki empat cara dalam menerapkan pendidikan karakter.

a. Al-Qur'an mengungkapkan realita yang dihadapi langsung oleh manusia

b. Al-Qur'an memberikan jawaban terhadap pertanyaan manusia terkait dengan alam semesta.

c. Al-Qur'an mendorong fitrah manusia untuk menyadari bahwa realitas alam ini butuh satu kekuatan yang mengaturnya.

d. Al-Qur'an mendorong manusia untuk tunduk kepada kholik dan kesiapan untuk merealisasikannya dalam kehidupan sehari-hari.

\section{Al-Qur'an sebagai rujukan karakter}

Al-Qur'an berfungsi menyampaikan risalah untuk menata sikap dan perilaku yang harus dilakukan manusia. Syeh Abdurrahman AnNahlawi (1999:84) berpendapat al-Quran memiliki dua macam petunjuk. Pertama berupa perintah, larangan dan informasi tentang perbuatan yang baik menurut syari'ah atau urf (kebiasaan) yang berdasarkan rasio, syari'at dan tradisi. Kedua memanfaatkan daya nalarnya untuk melakukan sesuatu yang bermanfaat baik untuk dirinya dan orang lain, sehingga banyak ayat al-Qur'an memberi instruksi agar manusia membangun karakter akhlak, yang berkenaan dengan perilaku, penjagaan diri, sifat baik.

\section{Nasihat Rasullulah SAW sebagai rujukan karakter}

Secara refleks, setiap wanita muslimah yang ditanya tentang metode pendidikan anak terbaik pasti kebanyakan akan menjawab 'yang islami'. Sederhana, namun tidak selalu berhasil menjawab berbagai pertanyaan tentang metode mendidik anak. 'Islami' di sini harus dilandaskan ilmu, bukan asal tempel untuk melegalisasi suatu perbuatan, seperti misalnya pacaran islami, sinetron islami, dan lain sebagainya. Maka mewujudkannya harus dilandasi ilmu yang benar dan tidak menyimpang dari Al-Qur'an dan sunnah Rasulullah SAW. Di tengah penelitian dan pengkajian tentang berbagai metode pendidikan yang terbaik, muncullah pertanyaan 'lalu bagaimana dengan Islam'? Apakah pendidikan menurut Islam itu cukup berkarakter? Karakternya siapa? Sebuah pertanyaan yang bisa dijawab dengan hanya mendatangkan satu hadits saja. Sebuah hadits yang seharusnya menjadi inspirasi bagi setiap orang tua dan pendidik 
dalam menjalankan perannya. Sebuah hadits yang seharusnya menjadi rujukan dan lebih didahulukan dari sekedar teori-teori psikologi terkini. Hadits yang mulia itu diriwayatkan oleh Tirmidzi sebagai berikut:

Abdullah bin 'Abbas radhiyallahu 'anhuma menceritakan, suatu hari saya berada di belakang Nabi shallallahu 'alaihi wasallam. Beliau bersabda, "Nak, aku ajarkan kepadamu beberapa untai kalimat; Jagalah Allah, niscaya Dia akan menjagamu, Jagalah Allah, niscaya kau dapati Dia di hadapanmu. Jika engkau hendak meminta, mintalah kepada Allah, dan jika engkau hendak memohon pertolongan, mohonlah kepada Allah. Ketahuilah, seandainya seluruh umat bersatu untuk memberimu suatu keuntungan, maka hal itu tidak akan kamu peroleh selain dari apa yang telah Allah tetapkan untukmu. Dan andaipun mereka bersatu untuk melakukan sesuatu yang membahayakanmu, maka hal itu tidak akan membahayakanmu kecuali apa yang telah Allah tetapkan untuk dirimu. Pena telah diangkat dan lembaran-lembaran telah kering".

Nasihat Rasulullah shalallahu 'alaihi wa sallam yang termaktub dalam hadits dari Ibnu Abbas radhiyallahu 'anhu seolah merangkum semua karakter hebat yang bisa diajarkan pada anak-anak kita. Perintah menjaga Allah adalah perintah untuk selalu menjaga diri dari perbuatan buruk atau maksiat yang dilarang oleh-Nya. Selain itu, menjaga Allah juga berarti kita berusaha melaksanakan semua perintahnya dengan menjaga amal ibadah kita sehari-hari. Jika anakanak kita sudah memiliki karakter selalu merasa diawasi oleh Allah, maka kita tidak perlu lagi memata-matai dengan siapa anak bergaul, kita tidak akan mengintip aktivitas anak dengan internet, kita tidak perlu lagi berteriak-teriak menyuruh anak sholat, dan bahkan mungkin pihak sekolah pun tidak perlu memasang CCTV ketika ujian berlangsung. Semua itu karena setiap anak merasa senantiasa diawasi oleh Allah yang outputnya akan menghasilkan sosok ulil albab yaitu:

a. Tauhidnya

b. Ilmu dan pengetahuannya

c. Sikap dan ibadahnya

d. Tafakkur dan tadabbur 


\section{Dasar Pembentukan Karakter Manusia}

Sebagai manusia kita memerlukan attitude untuk berinteraksi dengan lingkungan dan makhluk Tuhan, sehingga kita memerlukan beberapa komponen pokok dalam kepribadian manusia yaitu:

1. Kepercayaan atau keyakinan terhadap ide dan konsep suatu objek.

2. Tingkat emosional atau evaluasi emosional terhadap suatu objek.

3. Kecenderungan untuk bertindak (Abdullah Yatimin, 2007: 215).

Pendidikan akhlak dalam Islam dapat dimaknai sebagai latihan mental dan fisik, sehingga dapat menghasilkan manusia yang berbudaya tinggi untuk melaksanakan tugas kewajiban dan juga rasa tanggung jawabnya selaku hamba Allah dan bersifat formal yang terstruktur. Dengan demikian akhlak merupakan pondasi dasar sebuah karakter diri, karena tujuan pendidikan dalam Islam adalah menciptakan manusia yang beriman dan bertakwa melalui ilmu pengetahuan dan berperilaku ssesuai dengan nilai-nilai Islam.

\section{Pendidikan Karakter sebagai Proses Transformasi Sosial}

Pandangan positif yang menyatakan pendidikan sebagai proses trasformasi sosial berangkat dari sebuah asumsi dasar bahwa kenyataan yang dialami oleh manusia merupakan sebuah proses. Setiap manusia senantiasa menjalani sebuah proses untuk "menjadi". Tak ada manusia yang sudah atau tiba-tiba "menjadi" sesuatu atau memahami sesuatu tanpa mengalami sebuah proses. Bahkan, proses yang dialami manusia di dunia ini adalah proses yang terus-menerus yang tak pernah berhenti, kecuali telah mengalami kematian. Ini artinya, meski seorang manusia mengalami atau dianggap telah "menjadi" sesungguhnya ia juga terus saja menjalani sebuah proses untuk "menjadi" tahap berikutnya. Dengan demikian, pendidikan memang penting bagi anak manusia agar proses yang dijalaninya akan menjadi lebih baik, agar proses yang dijalaninya justru tidak menjauhkan dirinya dari hakikat kemanusiaannya.

Berkaitan dengan pendidikan bagi anak manusia dalam menjalani proses untuk "menjadi" ini, tentu pendidikan tidak bisa dilepaskan dari persoalan sosial yang sedang terjadi. Pendidikan yang hanya membekali peserta didik dengan pengetahuan yang tidak mencerahkan terkait kehidupan sosial atau justru malah membuat kemanusiaan tertindas secara sosial semestinya ditinggalkan. Inilah hal penting dari pendidikan sebagai proses yang membebaskan. Sebuah proses pendidikan yang meninggalkan cara dan aktivitas yang 
sesungguhnya justru dehumanisasi menuju cara dan aktivitas pendidikan yang penuh dengan proses humanisasi.

Dengan menjadikan pendidikan sebagai cara dan aktivitas yang penuh dengan proses humanisasi, hal ini sesungguhnya telah menjadikan pendidikan sebagai sebuah proses transformasi sosial menuju perubahan ke arah kemajuan di tengah masyarakat. Proses pendidikan ini ditandai dengan adanya peralihan situasi dari: teologi tradisional menuju teologi pembebasan, proses yang tidak mengenal dialog menuju hubungan yang penuh dialogis, kehidupan masyarakat yang tertutup menuju kehidupan masyarakat yang terbuka, dan masyarakat yang jauh dari pengetahuan menuju masyarakat yang sadar serta membutuhkan ilmu pengetahuan. Dengan demikian, pendidikan merupakan suatu sarana untuk memproduksi kesadaran dalam rangka mengembalikan manusia kepada hakikat kemanusiaannya.

Terkait dengan pendidikan sebagai sarana untuk memproduksi kesadaran untuk mengembalikan manusia kepada hakikat kemanusiaannya, maka pendidikan harus bisa berperan membangkitkan kesadaran kritis para peserta didik. Ini adalah sebagai prasyarat penting menuju pembebasan. Terkait dengan masalah ini, salah satu tugas penting pendidikan adalah melakukan refleksi kritis terhadap sistem dan ideologi yang dominan dan menguasai masyarakat pada umumnya. Refleksi kritis ini dilakukan dalam rangka untuk memikirkan sistem alternatif ke arah transformasi sosial menuju kehidupan masyarakat yang berkeadilan.

Pendidikan dikaitkan dengan Islam, dalam hal ini pendidikan Islam tidak saja dipersepsi dan dipahami sebagai pendidikan tentang agama Islam, seperti dipahami orang-orang selama ini, tetapi juga pendidikan menurut Islam. Pendidikan Islam secara konseptual dan kontekstual memiliki muatan teologi sosial kritis dan memahami sains. Di sini agama memiliki fungsi membebaskan, dimana agama sendiri pada dasarnya timbul sebagai protes yang sah melawan masyarakat yang tidak adil dan dan karup cara hidupnya. Dalam upaya meletakkan dasar yang kokoh bagi kehidupan seseorang demi perbaikan nasib manusia seluruhnya. Dengan demikian fungsi agama bagi kemanusiaan akan tampak jika refleksi terhadap agama dapat diterapkan dalam kehidupan atau prilaku sosial. 
Pendidikan Islam memiliki unsur universalitas (terlihat dalam konsep rahmatan lil'alamin), emansipatoris dan egalitarian, meminjam bahasanya Ali Syari'ati, Islam menggambarkan sebuah pandangan yang mencakup seluruh segi kehidupan selain memperhatikan masalah-masalah sosial, Islampun merupakan sebuah mazhab pemikiran yang menjamin kehidupan manusia baik individu maupun kelompok dan misinya adalah membimbing masa depan umat manusia (Hamid Algar, 2011: 42). Peran kritis Islam seharusnya terinternalisasi dalam konsep pendidikan Islam. artinya pendidikan Islam harus mampu menjadi instrumen pembebas dan sebagai proses adanya transformasi sosial. Bila dilihat dari awal penurunan alQur'an, diturunkannya lima ayat pertama Q.S Al-Alaq: 1-5 memiliki muatan komponen pendidikan. Ayat-ayat tersebut memberikan jawaban yang mempertimbangkan sosiologis dan kemanusiaan. Penurunan lima ayat tersebut jika dilihat dari aspek historis memiliki fungsi sebagai proses transformasi sosial yang terkandung di dalamnya upaya penyadaran dan pembebasan masyarakat dari sistem perbudakan yang disebabkan oleh sistem pembodohan yang dilakukan oleh masyarakat kelas atas. Pendidikan pada masa itu sampai sekarang pun tidak berpihak pada masyarakat lemah dan hanya menciptakan bangsawan-bangsawan borjuis yang sombong. Namun dengan datangnya Islam dan diturunkan lima ayat tersebut mengandung nilai bahwa pendidikan terkait dengan perubahan yang terjadi pada masyarakat.

Pendidikan Islam memiliki misi untuk melakukan transformasi sosial, sebagaimana yang dikemukakan Fazlurrahman dalam bukunya Islam and Modernity, Transformation ot an intellectual tradition. Islam tidak saja sebagai agama wacana tetapi Islam juga sebagai sebagai agama transformatif. Dengan kata lain eksistensi Islam dalam berbagai era kebudayaan sangat ditentukan oleh intensitas transformasi intelektual, dengan demikian pendidikan Islam selain memiliki misi transfer or religious value juga memiliki fungsi sebagai media dan instrumen pembebasan. Pendidikan Islam menjadikan peserta didik dan masyarakat sekitarnya menjadi manusia bebas dan terbebaskan, dari pola atau sistem yang membelenggu. Di sini pendidikan mampu menempatkan manusia pada posisi sentral dalam setiap perubahan yang terjadi dan mampu pula menyarankan serta mengendalikan perubahan. Menjadikan manusia bebas atau 
kebebasan menusia sebagai sosok yang harus dilahirkan dari proses pendidikan.

Menurut Al-attas (1981:177) ada dua pandangan teoritis mengenai tujuan pendidikan secara umum yang sesuai dengan tingkat keragaman pertama mengangap pendidikan sebagai sarana dalam menciptakan rakyat yang berkarakter di berbagai bidang. Kedua individu yang memfokuskan diri pada kebutuhan akan wawasan dan ilmu pengetahuan dan mengembalikan manusia kepada fitrah kemanusiaanya bukan semata mengembankan intelektual saja. Melihat tujuan dari pendidikan, pendidikan memiliki fungsi yang strategis dalam proses transformasi sosial. Melalui pendidikan diharapkan lahir individu-individu terdidik yang mampu mengubah penindasan serta membebaskan dari ketidakadilan sosial yang terjadi karena transformasi sosial itu ditentukan oleh masyarakat yang terkait dengan individu-individu terdidik, sebagaimana diuraikan oleh Ali Syari'ati (1995: 210).

"Individu-individu terdidik mungkin bisa menjadi pemula yang baik, tetapi dalam rangka menterjemahkan ideologi ke dalam realitas dan mendorongnya menuju kesempurnaan, masyarakatlah yang selalu menjadi elemen-elemen yang praktis dan bertanggung jawab".

\section{Simpulan}

Pendidikan karakter di Indonesia tidak bisa dilihat seperti masa yang lalu, hanya dengan pelajaran Pkn lalu dianggap sebagai pendidikan karakter sudah diimplementasikan tentunya tidak sesederhana itu, pendidikan karakter sama saja kita menyedehanakan eksistensi manusia dan memperhatikan pendidikan karakter adalah salah satu bentuk memuliakan manusia yaitu peserta didik. Islam tentu sangat memuliahkan manusia, proses pendidikan dan pembinaan manusia dalam konsep pendidikan karakter di perkaya oleh contoh ideal, yaitu madrasah nabawi, (model pendidikan Nabi). Madrasah nabawi tersebut berhasil mengubah karakter manusia dari jahiliyah menjadi Islamiyah sehingga berubah menjadi 180 derajat. 


\section{DAFTAR PUSTAKA}

Abdullah, Muhammad Yatimin. 2007. Studi Akhlak Dalam Perspektif Al-Quran Dan As-Sunnah, Amzah: Jakarta.

Abdullah, Yatimin. 2007. Studi Akhlak dalam Perspektif al Quran, Amzah: Jakarta.

Abdul Azis Sachedina "Ali Syari'ati; Ideologue Of The Iranian Revolution" dalam John L. Esposito (ed.) Voice of Resurgent Islam. New York: Oxford University Press, 1983

Abdurrahman An-Nahlawi. 1999. Pendidikan Islam di Rumah di Sekolah dan Masyarakat, Gema Insani Press: Yogyakarta.

Ahmad Tafsir. 1995. Metodik Khusus Pendidikan Islam, Remaja Rosdakarya: Bandung.

Alavi,. 2003. Muhammad Zianudin, Pemikiran Pendidikan Islam Pada abad klasik dan Pertengahan, Angkasa: Jakarta.

Al-Attas, Syed Muhammad Naquib. 1981. Islam dan Sekularisme, Penerbit Pustaka: Bandung.

Ali Syariati. 1994. On The Sosiologi of Islam, Trans. Hamid Algar, Mizan: Barkeley.

Arifin, Muzayyi. 2005. Filsafat Pendidikan Islam, Bumi Aksara: Jakarta.

An Nahlawi, Abdurrahman. 1995. Pendidikan Islam Di Rumah Sekolah Dan Masyarakat, Angkasa: Jakarta.

Hamid, Algar. 2011. Wahabisme Sebuah Tinjauan Kritis, Democracy Project: Jakarta.

Herman, H. Horn. 1962. An Idialistic Philosophy of Education, Part I. The University of Chicango Press: Chichango. 
Paulo, Freire. 1984. Pendidikan Sebagai Praktek Pembebasan, Terj. Alois A. Nugroho, Gramedia: Jakarta.

Syari'ati, Ali. 1995. Islam Mazhab Pemikiran dan Aksi, terjemahan M.S. Nasrulloh dan Afif Muhammad, Mizan: Bandung. 